\title{
EROSI DAN KEHILANGAN HARA PADA PERTANAMAN KENTANG DENGAN BEBERAPA SISTEM GULUDAN PADA ANDISOL DI HULU DAS MERAO, KABUPATEN KERINCI, JAMBI ${ }^{*}$
}

\author{
Henny H. ${ }^{1)}$, K. Murtilaksono ${ }^{2}$, N. Sinukaban ${ }^{2)}$ dan S. D. Tarigan ${ }^{2)}$ \\ 1) Dosen F akultas Pertanian U niversitas J ambi \\ 2) Dosen Fakultas Pertanian, IPB, Bogor \\ ${ }^{*}$ B Bagian dari Disertasi
}

\begin{abstract}
This research was aimed to study alternative techniques for soil conservation in controlling erosion and nutirients lost from Andisol planted with potatoes in upper part of Merao watershed, in Kerinci Region, Jambi Province. The research was conducted in Kebun Baru, Kayu Aro, Kerinci. The soil and sediment samples were analysed at Soil and Land Resource Laboratory, Agriculture Faculty, Institute Pertanian Bogor. Erosion was measured on small plots consisting of seven (7) treatments and three (3) replications considered as blocks. The results showed that planting potatoes across the slope direction, or making soil bed across $15 \%$ slope, or soil bed as slope direction and across slope direction every $4.5 \mathrm{~m}$ distance could control erosion and nutrients lost, and did not affect potato yield compared to soil bed as slope direction. Planting potatoes on soil bed as slope and across slope direction in each 4,5 m distance (modified farmers model) reduced erosion, soil organic-C, and total-N lost for $65.89,65.19$, and $24.55 \%$, respectively, compared to planting as slope direction.
\end{abstract}

Keywords: erosion, nutrient lost, sedimentation

\section{PENDAHULUAN}

Kabupaten Kerinci merupakan sentra produksi sayuran dataran tinggi di Propinsi Jambi dengan kentang sebagai komoditas unggulan (Bappeda Kabupaten Kerinci 2004). Areal utama usahatani kentang tersebut adalah Kecamatan Kayu Aro, berada di hulu daerah aliran sungai (DAS) Merao pada dataran tinggi Gunung Kerinci. Hulu DAS memiliki potensi strategis sebagai kawasan pertanian produktif dalam pembangunan pertanian nasional dan telah lama dimanfaatkan oleh petani setempat untuk memenuhi kebutuhan sehari-hari dan menopang ekonomi keluarga. Selain memberikan manfaat bagi petani, hulu DAS juga berperan penting dalam menjaga fungsi lingkungan DAS dan penyangga daerah di bawahnya. Namun lahan di hulu DAS tersebut umumnya peka terhadap erosi, karena merupakan lahan kering dataran tinggi yang didominasi oleh tanah dengan bahan induk abu vulkan (Andisol) pada wilayah berombak, bergelombang hingga berbukit (Hidayat \& Mulyani 2002).
Ketergantungan penduduk terhadap lahan di hulu DAS Merao cukup tinggi karena usaha pertanian merupakan sumber utama pendapatan sebagian besar masyarakat, terutama dari usaha budidaya tanaman hortikultura sayuran dataran tinggi. Pengelolaan lahan umumnya tanpa upaya konservasi tanah dengan teknik budidaya yang tidak sesuai dengan kondisi tanah dan kebutuhan tanaman. Kondisi ini terutama terjadi di Kecamatan Kayu Aro. Petani disini menanam kentang, kubis, cabe, tomat dan sayuran lainnya pada guludan searah lereng. Diprediksi erosi pada pertanian campuran di hulu DAS Merao sebesar 60180 ton/ha/tahun dengan tingkat bahaya erosi sedang hingga berat, lebih besar dari erosi yang dapat ditoleransikan yang hanya 22.5-41.6 ton/ha/tahun (BP DAS Batanghari 2003).

Dewasa ini telah diketahui berbagai teknik konservasi tanah yang efektif mengendalikan aliran permukaan dan erosi. Sejumlah hasil penelitian pada beberapa sentra produksi kentang dataran tinggi menunjukkan bahwa penanaman kentang 
pada guludan memotong lereng (searah kontur) dapat mengendalikan erosi dan tidak menurunkan hasil (Suganda et al. 1999, Haryati \& Kurnia 2000, Sinukaban 2007) serta dapat mengurangi aliran permukaan, quickflow, annual water yield dan meningkatkan base flow di dalam DAS (Sinukaban et al. 1998). Namun hingga saat ini penerapan teknik konservasi masih belum merupakan bagian dari pengelolaan lahan oleh petani umumnya dan petani kentang khususnya.

Salah satu faktor yang mempengaruhi implementasi teknik konservasi tanah di Indonesia adalah aspek kultur/budaya petani, termasuk disini kebiasaan petani atau ketidak-pedulian pentingnya upaya konservasi tanah (Murtilaksono 1998). Hal ini sesuai dengan hasil survei di beberapa sentra produksi kentang yang menunjukkan bahwa petani umumnya enggan menerapkan penanaman pada guludan searah kontur (memotong lereng) karena beranggapan: 1) sulit, berat dan membutuhkan waktu yang lebih lama dalam mengerjakannya; dan 2) setelah hujan menyebabkan genangan air pada saluran diantara guludan yang meningkatkan kelembaban tanah di dalam guludan tersebut sehingga merupakan media bagi berkembangnya jamur penyebab penyakit busuk akar atau umbi. Oleh karena itu teknik konservasi tanah yang akan dapat diterima petani adalah penerapan guludan sesuai dengan agroekosistem setempat tanpa mengabaikan kebiasaan petani dan erosi dapat dikendalikan sampai batas aman dan tidak menurunkan hasil (Kurnia et al. 2004).

Penelitian ini bertujuan untuk mengkaji beberapa alternatif teknik konservasi tanah yang dapat mengendalikan aliran permukaan, erosi dan kehilangan hara pada pertanaman kentang, sekaligus tidak mengurangi hasil pada Andisol di hulu DAS Merao, Kecamatan Kayu Aro, Kabupaten Kerinci, Propinsi Jambi.

\section{BAHAN DAN METODE}

Tempat dan Waktu

Penelitian di laksanakan di Desa Kebun Baru, Kecamatan Kayu Aro, Kabupaten Kerinci, Propinsi Jambi. Analisis contoh tanah dan sedimen dilakukan di Laboratorium Departemen Ilmu Tanah dan Sumberdaya Lahan Fakultas Pertanian Institut Pertanian Bogor. Penelitian berlangsung dari bulan Januari hingga Mei 2008.

Bahan dan Alat

Bahan-bahan yang digunakan adalah benih kentang Varietas Granola (G-3), pupuk kandang, pupuk buatan (Urea, ZA, SP-36, KCl), fungisida (Dithane M-45, Curzate, Amistartop), insektisida (Matador, Virtako), nematisida (Furadan), herbisida (Gramaxon) dan sejumlah bahan kimia untuk analisis tanah di laboratorium. Peralatan yang digunakan adalah bak penampung aliran permukaan dan erosi, plastik terpal, bambu, cangkul, alat penakar hujan, dan seperangkat alat laboratorium untuk analisis tanah dan sedimen di laboratorium.

\section{Rancangan Percobaan}

Penelitian berupa percobaan erosi petak kecil menggunakan Rancangan Acak Kelompok (RAK) dengan 7 perlakuan dan 3 ulangan (sekaligus sebagai kelompok) masing-masing pada kemiringan lereng 8, 14 dan 20 persen. Satuan percobaan berupa petakan $10 \mathrm{~m}$ x $2 \mathrm{~m}$ (panjang petak searah lereng). Ketujuh perlakuan tersebut adalah : 1) Penanaman pada guludan searah lereng (sistem petani) $\left.\left(\mathrm{P}_{0}\right), 2\right)$ Penanaman pada guludan searah lereng +2 guludan memotong lereng di bagian tengah dan ujung bawah petakan $\left.\left(\mathrm{P}_{1}\right), 3\right) \mathrm{P}_{1}+1$ rorak kecil pada guludan di ujung bawah petakan $\left(\mathrm{P}_{2}\right)$, 4) $\mathrm{P}_{1}+1$ rorak kecil pada masingmasing guludan memotong lereng $\left.\left(\mathrm{P}_{3}\right), 5\right)$ Penanaman pada guludan memotong lereng $\left.\left(\mathrm{P}_{4}\right), 6\right)$ Penanaman pada guludan memotong lereng miring $15^{0}\left(\mathrm{P}_{5}\right)$, dan 7) Penanaman pada guludan memotong lereng miring $30^{\circ}$ $\left(\mathrm{P}_{6}\right)$.

Pengukuran aliran permukaan dan erosi dengan Metode Multi-slot Diviser. Pembatas petakan percobaan adalah plastik terpal $( \pm 20 \mathrm{~cm}$ ke dalam tanah dan $\pm 20 \mathrm{~cm}$ di atas permukaan tanah. Bak penampung aliran permukaan dan erosi berukuran $2 \mathrm{~m} \mathrm{x}$ $0.5 \mathrm{~m} \times 0,5 \mathrm{~m}$ dengan 7 lubang (diameter 5 $\mathrm{cm})$ pada $5 \mathrm{~cm}$ dari bibir bak dan satu 
lubang yang ditengah dihubungkan dengan pipa paralon (diameter $5 \mathrm{~cm}$ ) untuk mengalirkan luapan ke bak kecil $0.5 \mathrm{~m}$ x 0.5 $\mathrm{m} \times 0.5 \mathrm{~m}$.

\section{Pelaksanaan Penelitian}

Penanaman kentang menggunakan jarak tanam $75 \mathrm{~cm} \times 30 \mathrm{~cm}$ (jarak antar guludan $75 \mathrm{~cm}$ dan jarak tanaman dalam guludan $30 \mathrm{~cm}$ ) dan pemupukan $150 \mathrm{~kg}$ Urea, $150 \mathrm{~kg}$ ZA, $350 \mathrm{~kg} \mathrm{SP-36,} 200 \mathrm{~kg} \mathrm{KCl}$ per hektar (Rekomendasi BPTP Jambi 2004) dan pupuk kandang 20 ton/ha. Bibit yang digunakan adalah varietas Granola (G-3) dari Balai Benih Induk Kentang (BBIK) Kayu Aro, Kabupaten Kerinci, Jambi. Pemberian pupuk kandang setelah pengolahan tanah secara larikan pada barisan tanaman. Penanaman dilakukan setelah pemberian pupuk kandang dan sekaligus pemberian pupuk buatan (Urea dan $\mathrm{KCl}$ masing-masing setengah dosis dan SP-36 dosis penuh) dengan cara tugal \pm 7 $\mathrm{cm}$ di dekat bibit tanaman. Pendangiran dan pemupukan susulan (setengah dosis Urea dan $\mathrm{KCl}$ ) dilakukan 30 hari setelah tanaman tumbuh. Pengendalian hama dan penyakit tanaman menggunakan insektisida dan fungisida dengan penyemprotan seminggu sekali (dosis sesuai anjuran) mulai tanaman berumur seminggu setelah tumbuh hingga tanaman dalam kondisi daun mulai layu.

Pengamatan dan pengumpulan data

Data yang dikumpulkan terdiri atas : 1) Sifat tanah sebelum perlakuan; 2) Aliran permukaan dan erosi; 3) Konsentrasi sedimen, 4) Distribusi partikel tanah dan konsentrasi C-organik, N, P dan $\mathrm{K}$ di dalam sedimen, 5) jumlah C-organik, N, P dan $\mathrm{K}$ terbawa erosi (kehilangan bahan organik dan unsur hara akibat erosi); 6) Hasil tanaman kentang; dan 7) Curah hujan selama percobaan.

Pengukuran aliran permukaan dan erosi dilakukan setiap pukul 07.00 pagi pada setiap kejadian hujan selama percobaan. Volume aliran permukaan (liter/petak) diukur dengan cara menakar air yang tertampung di dalam bak penampung. Berat tanah tererosi diperoleh dengan cara menimbang semua tanah basah (sudah dikeringanginkan), kemudian diambil contoh tanah tersebut $( \pm 25$ g) dan dikeringkan di dalam oven hingga beratnya tetap $( \pm 3$ jam $)$ sehingga dapat dihitung berat total tanah tererosi (Sitorus \& Tirtohadisurjo 1979). Konsentrasi sedimen diukur melalui contoh sedimen $( \pm 500 \mathrm{ml})$ yang diambil menggunakan botol plastik di ujung bawah petak percobaan sebelum aliran permukaan masuk ke dalam bak penampung. Konsentrasi sedimen (g/l) ditetapkan di laboratorium dengan cara pengeringan di oven. Kemudian dari contoh sedimen tersebut dilakukan analisis distribusi ukuran partikel untuk mengetahui konsentrasi pasir, debu dan liat (\%) (Metode Pipet), kandungan C-organik (Metode Walkley dan Blake), N-total (Metode Kjeldhal), Ptersedia (Metode Bray-1) dan K-tersedia (ekstraksi dengan $1 \mathrm{~N} \mathrm{NH}_{4} \mathrm{OAc} \mathrm{pH}$ 7.0). Jumlah C-organik, N, P dan $\mathrm{K}$ yang terbawa erosi dihitung berdasarkan konsentrasi $\mathrm{C}$ organik, N, P dan $\mathrm{K}$ di dalam sedimen dan jumlah tanah tererosi.

Analisis Data

Data hasil percobaan dianalisis secara statistik menggunakan Uji-F dan dilanjutkan dengan Uji Duncan (Duncan New Multiple Range Test) untuk mengetahui perbedaan pengaruh antar perlakuan dan perlakuan terbaik.

\section{HASIL DAN PEMBAHASAN}

\section{Aliran permukaan dan erosi}

Aliran permukaan dan erosi nyata lebih kecil pada pertanaman dengan guludan memotong lereng $\left(\mathrm{P}_{4}\right)$ dan guludan memotong lereng miring 15 dan 30 derajat $\left(\mathrm{P}_{5}\right.$ dan $\left.\mathrm{P}_{6}\right)$, dibandingan dengan penanaman pada guludan searah lereng $\left(\mathrm{P}_{0}\right)$ (Tabel 1). Hal ini disebabkan guludan memotong lereng dapat berperan sebagai penghambat sehingga mengurangi kecepatan aliran permukaan, akibatnya sebagian air hujan yang jatuh di permukaan tanah mempunyai waktu yang lebih lama untuk masuk ke dalam tanah. Sebaliknya pada pertanaman dengan arah guludan searah lereng, air hujan yang jatuh di permukaan tanah relatif lebih sedikit yang bisa masuk ke dalam tanah dan 
sebagian besar langsung mengalir sebagai aliran permukaan akibat tidak adanya penghambat aliran di permukaan tanah. Guludan memotong lereng yang dapat

Tabel 1. Pengaruh sistem guludan tanaman kentang terhadap aliran permukaan dan erosi pada Andisol Desa Kebun Baru di hulu DAS Merao, Kabupaten Kerinci Jambi

\begin{tabular}{cccrrc}
\hline Perlakuan & \multicolumn{3}{c}{ Aliran permukaan } & \multicolumn{2}{c}{ Erosi } \\
\cline { 2 - 6 } & ltr/ptk & $\mathrm{mm}$ & $\% \mathrm{CH}$ & $\mathrm{kg} / \mathrm{ptk}$ & ton/ha \\
\hline $\mathrm{P}_{0}$ & 3045.81 & $152.29 \mathrm{a}$ & 17.92 & 58.09 & $22.94 \mathrm{a}$ \\
$\mathrm{P}_{1}$ & 1978.55 & $98.93 \mathrm{c}$ & 11.64 & 19.24 & $9.62 \mathrm{~cd}$ \\
$\mathrm{P}_{2}$ & 1848.36 & $92.42 \mathrm{~cd}$ & 10.88 & 19.99 & $9.99 \mathrm{c}$ \\
$\mathrm{P}_{3}$ & 1671.25 & $83.56 \mathrm{~d}$ & 9.83 & 15.63 & $7.81 \mathrm{de}$ \\
$\mathrm{P}_{4}$ & 1128.04 & $51.40 \mathrm{e}$ & 6.05 & 8.62 & $4.31 \mathrm{e}$ \\
$\mathrm{P}_{5}$ & 1736.82 & $86.84 \mathrm{~d}$ & 10.22 & 8.91 & $4.45 \mathrm{e}$ \\
$\mathrm{P}_{6}$ & 2201.58 & $110.08 \mathrm{~b}$ & 12.95 & 35.08 & $17.54 \mathrm{~b}$ \\
\hline
\end{tabular}

* Angka-angka yang diikuti oleh huruf yang sama pada kolom yang sama tidak berbeda nyata pada taraf $5 \%$ menurut DNMRT; * $\mathrm{CH}$ (Curah Hujan) $849.79 \mathrm{~mm}$

mengurangi kecepatan dan energi aliran permukaan pada gilirannya juga dapat mengurangi jumlah tanah yang terbawa aliran permukaan atau erosi. Sebaliknya dengan penanaman kentang pada guludan searah lereng, air hujan yang jatuh di permukaan tanah tidak mempunyai waktu yang lama untuk masuk ke dalam tanah dan mengalir dengan cepat di permukaan karena tidak ada penghalang aliran permukaan tersebut. Akibatnya air hujan yang jatuh langsung mengalir dengan kecepatan lebih tinggi dan mengikis permukaan tanah, sehingga aliran permukaan dan erosi lebih besar.

Penanaman pada guludan memotong lereng $\left(\mathrm{P}_{4}\right)$ dapat menekan erosi $(81.21 \%)$ dibandingkan dengan penanaman searah lereng $\left(\mathrm{P}_{0}\right)$. Namun efektivitasnya mengendalikan aliran permukaan berkurang dengan guludan memotong lereng miring 15 dan 30 derajat $\left(\mathrm{P}_{5}\right.$ dan $\left.\mathrm{P}_{6}\right)$, karena guludan miring tersebut menyebabkan air hujan yang jatuh di permukaan tanah mengalir lebih cepat akibat berkurangnya waktu untuk masuk ke dalam tanah, sehingga volume aliran permukaan menjadi lebih besar. Sementara itu kemampuan menekan erosi pada $\mathrm{P}_{5}$ tidak berbeda nyata dibandingkan dengan $\mathrm{P}_{4}$ yang dapat menekan erosi (65.89 $\%$ ) dibandingkan dengan $\mathrm{P}_{0} . \quad \mathrm{Hal}$ ini disebabkan guludan memotong lereng meskipun miring 15 derajat masih mampu berperan mengurangi pengikisan permukaan tanah oleh aliran permukaan dan menahan hanyutnya tanah dan melalui pengurangan kecepatan aliran permukaan tersebut.

Penanaman pada guludan searah lereng juga dapat mengendalikan aliran permukaan dan erosi dengan adanya guludan memotong lereng pada setiap jarak $4.5 \mathrm{~m}\left(\mathrm{P}_{1}\right.$, $\mathrm{P}_{2}, \mathrm{P}_{3}$ ). Dalam hal ini aliran permukaan dan erosi masih lebih besar dibandingkan dengan perlakuan $\mathrm{P}_{4}$, namun nyata lebih kecil dibandingkan dengan perlakuan $\mathrm{P}_{0}$. Adanya lubang kecil yang dapat menampung dan menahan aliran pada guludan memotong lereng dapat meningkatkan efektivitasnya mengendalikan aliran permukaan dan erosi $\left(\mathrm{P}_{2}\right.$ dan $\mathrm{P}_{3}$ ). Erosi pada $\mathrm{P}_{3}$ (ada lubang kecil pada masing-masing guludan memotong lereng) nyata lebih kecil dibandingkan $\mathrm{P}_{0}$ (penanaman searah lereng) dan tidak berbeda nyata dengan erosi pada perlakuan $\mathrm{P}_{4}$ (penanaman memotong lereng).

Distribusi partikel tanah dan konsentrasi hara di dalam sedimen

Distribusi partikel tanah di dalam sedimen pada perlakuan $\mathrm{P}_{0}$ (pasir $18.02 \%$, debu $75.46 \%$, liat $6.75 \%$ ) (Tabel 2) hampir sama dengan distribusi partikel tanah asalnya (pasir $20.83 \%$, debu $72.49 \%$, liat $6.68 \%$, Lampiran 1). Hal ini menunjukkan bahwa erosi pada petak perlakuan $\mathrm{P}_{0}$ relatif tidak selektif, karena cukup tingginya kemampuan transportasi aliran permukaan terhadap tanah permukaan akibat adanya saluran/parit diantara guludan searah lereng. Kondisi ini sebagaimana dikemukakan oleh 
Sinukaban (2007) dan (Arsyad (2009) bahwa selektivitas erosi terhadap fraksi halus tanah (liat) ditunjukkan oleh lebih tingginya kandungan fraksi halus di dalam

Tabel 2. Pengaruh sistem guludan tanaman kentang terhadap konsentrasi sedimen, distribusi partikel tanah dan konsentrasi hara di dalam sedimen pada Andisol Desa Kebun Baru di hulu DAS Merao, Kabupaten Kerinci, Jambi

\begin{tabular}{lclrcccc}
\hline $\begin{array}{c}\text { Perla } \\
\text {-kuan }\end{array}$ & $\begin{array}{c}\text { Pasir } \\
(\%)\end{array}$ & $\begin{array}{c}\text { Debu } \\
(\%)\end{array}$ & $\begin{array}{c}\text { Liat } \\
(\%)\end{array}$ & $\begin{array}{c}\mathrm{C}- \\
\text { organik } \\
(\%)\end{array}$ & $\begin{array}{c}\mathrm{N}- \\
\text { total } \\
(\%)\end{array}$ & $\begin{array}{c}\mathrm{P}- \\
\text { tersedia } \\
(\mathrm{ppm}\end{array}$ & $\begin{array}{c}\mathrm{K}- \\
\text { tersedia } \\
\text { me/100g }\end{array}$ \\
\hline $\mathrm{P}_{0}$ & $18.02 \mathrm{a}$ & $75.46 \mathrm{a}$ & $6.75 \mathrm{~b}$ & $9.73 \mathrm{~d}$ & $2.73 \mathrm{~b}$ & $32.09 \mathrm{c}$ & $0.29 \mathrm{~b}$ \\
$\mathrm{P}_{1}$ & $15.81 \mathrm{a}$ & $73.91 \mathrm{ab}$ & $10.27 \mathrm{a}$ & $15.43 \mathrm{bc}$ & $4.67 \mathrm{ab}$ & $43.66 \mathrm{~b}$ & $0.56 \mathrm{ab}$ \\
$\mathrm{P}_{2}$ & $15.28 \mathrm{a}$ & $72.35 \mathrm{~b}$ & $12.75 \mathrm{a}$ & $8.67 \mathrm{ab}$ & $4.89 \mathrm{ab}$ & $50.53 \mathrm{ab}$ & $0.77 \mathrm{a}$ \\
$\mathrm{P}_{3}$ & $14.93 \mathrm{a}$ & $72.95 \mathrm{ab}$ & $12.35 \mathrm{a}$ & $9.95 \mathrm{ab}$ & $6.05 \mathrm{ab}$ & $54.05 \mathrm{a}$ & $0.79 \mathrm{a}$ \\
$\mathrm{P}_{4}$ & $14.97 \mathrm{a}$ & $74.42 \mathrm{ab}$ & $12.17 \mathrm{a}$ & $22.06 \mathrm{a}$ & $7.94 \mathrm{a}$ & $55.70 \mathrm{a}$ & $0.92 \mathrm{a}$ \\
$\mathrm{P}_{5}$ & $16.08 \mathrm{a}$ & $72.07 \mathrm{~b}$ & $12.52 \mathrm{a}$ & $23.09 \mathrm{a}$ & $5.79 \mathrm{ab}$ & $55.75 \mathrm{a}$ & $0.84 \mathrm{a}$ \\
$\mathrm{P}_{6}$ & $18.37 \mathrm{a}$ & $74.38 \mathrm{ab}$ & $7.25 \mathrm{~b}$ & $11.66 \mathrm{~cd}$ & $3.37 \mathrm{~b}$ & $34.53 \mathrm{c}$ & $0.36 \mathrm{~b}$ \\
\hline
\end{tabular}

* Angka-angka yang diikuti oleh huruf yang sama pada kolom yang sama tidak berbeda nyata pada taraf $5 \%$ menurut DNMRT

sedimen dibandingkan dengan tanah asalnya terkait dengan daya angkut aliran permukaan terhadap butir-butir ta

nah yang berbeda berat jenisnya.

Kandungan liat di dalam sedimen dari petakan yang mempunyai guludan memotong lereng $\left(\mathrm{P}_{1}, \mathrm{P}_{2}, \mathrm{P}_{3}, \mathrm{P}_{4}\right)$ dan guludan memotong lereng miring 15 derajat $\left(\mathrm{P}_{5}\right)$ nyata lebih tinggi dibandingkan kandungan liat sedimen dari petakan dengan penanaman pada guludan searah lereng $\left(\mathrm{P}_{0}\right)$ dan penanaman pada guludan memotong lereng miring 30 derajat $\left(\mathrm{P}_{6}\right)$ maupun dengan tanah asalnya; sebaliknya kandungan pasir lebih kecil (Tabel 2). Hal ini menunjukkan bahwa erosi lebih selektif pada partikel yang lebih halus (liat) dengan adanya guludan memotong lereng yang menciptakan hambatan terhadap aliran permukaan (memperlambat aliran permukaan) sehingga partikel yang lebih kasar (pasir) akan tertinggal atau mengendap terlebih dahulu; sedangkan partikel yang lebih halus (liat) sebagian besar tetap berada dalam suspensi dan terangkut bersama aliran permukaan. Hal ini sebagaimana dikemukakan oleh Johnson et al. (1979) bahwa pada umumnya energi aliran permukaan akan menurun apabila terdapat hambatan seperti adanya tindakan konservasi tanah, permukaan yang kasar atau sisa-sisa tanaman di permukaan tanah. Oleh karena itu teknik pengelolaan tanah dan tanaman yang dapat menurunkan energi aliran permukaan dapat meningkatkan selektivitas erosi dan sekaligus akan menurunkan jumlah tanah tererosi. Sebaliknya pada lahan dengan penanaman pada guludan searah lereng, erosi kurang selektif akibat aliran permukaan mengalir relatif tanpa hambatan sehingga partikel pasir, debu dan liat terbawa bersama aliran permukaan.

Tingginya kandungan liat di dalam sedimen (karena lebih selektifnya erosi) diikuti oleh tingginya konsentrasi C-organik dan unsur hara $(\mathrm{N}, \mathrm{P}, \mathrm{K})$ di dalam sedimen tersebut (Tabel 2). Hal ini disebabkan bahan organik dan unsur hara umumnya terjerap pada partikel halus seperti liat dan koloid. Disamping itu tingginya konsentrasi Corganik dan unsur hara di dalam sedimen juga dapat disebabkan oleh adanya bentukbentuk larut dari hasil pelapukan sisa tanaman pupuk organik dan pupuk buatan yang digunakan. Kandungan C-organik, Ntotal, $\mathrm{P}$ dan $\mathrm{K}$ tersedia di dalam sedimen pada perlakuan yang mempunyai guludan memotong lereng terutama $\mathrm{P}_{2}, \mathrm{P}_{3}, \mathrm{P}_{4}$ dan $\mathrm{P}_{5}$ nyata lebih tinggi dibandingkan dengan kandungannya pada sedimen dari perlakuan guludan searah lereng $\left(\mathrm{P}_{0}\right)$ maupun guludan memotong lereng tetapi miring 30 derajat $\left(\mathrm{P}_{6}\right)$. Kondisi ini mendukung bahwa erosi lebih selektif pada fraksi halus tanah (liat) 
pada perlakuan yang dapat mengurangi daya angkut aliran permukaan.
Jumlah C-organik dan hara N, P dan $\mathrm{K}$ terbawa erosi

Jumlah C-organik, N, P dan K yang hilang (terbawa oleh) erosi nyata lebih kecil

Tabel 3. Pengaruh sistem guludan tanaman kentang terhadap jumlah C-organik, N-total, P dan K-terbawa erosi pada Andisol Desa Kebun Baru di hulu DAS Merao, Kabupaten Kerinci, Jambi

\begin{tabular}{ccccc}
\hline Perlakuan & C-organik & N-total & $\mathrm{P}_{2} \mathrm{O}_{5}$ & $\mathrm{~K}_{2} \mathrm{O}$ \\
\hline & $\ldots \ldots \ldots \ldots \ldots \ldots \ldots \ldots \ldots \ldots \ldots \ldots \ldots \ldots \ldots \ldots \ldots \ldots \ldots \ldots \ldots \ldots \ldots \ldots \ldots \ldots \ldots \ldots \ldots \ldots \ldots$ \\
$\mathrm{P}_{0}$ & $2232.06 \mathrm{a}$ & $626.26 \mathrm{a}$ & $0.74 \mathrm{a}$ & $2.60 \mathrm{ab}$ \\
$\mathrm{P}_{1}$ & $1484.37 \mathrm{ab}$ & $449.25 \mathrm{ab}$ & $0.42 \mathrm{~b}$ & $2.11 \mathrm{ab}$ \\
$\mathrm{P}_{2}$ & $866.13 \mathrm{ab}$ & $488.51 \mathrm{a}$ & $0.51 \mathrm{ab}$ & $3.01 \mathrm{a}$ \\
$\mathrm{P}_{3}$ & $777.09 \mathrm{ab}$ & $472.50 \mathrm{a}$ & $0.42 \mathrm{~b}$ & $2.41 \mathrm{ab}$ \\
$\mathrm{P}_{4}$ & $950.78 \mathrm{~b}$ & $342.21 \mathrm{~b}$ & $0.24 \mathrm{c}$ & $1.55 \mathrm{ab}$ \\
$\mathrm{P}_{5}$ & $1027.50 \mathrm{~b}$ & $257.65 \mathrm{~b}$ & $0.25 \mathrm{c}$ & $1.46 \mathrm{~b}$ \\
$\mathrm{P}_{6}$ & $2045.16 \mathrm{a}$ & $588.06 \mathrm{a}$ & $0.61 \mathrm{a}$ & $2.47 \mathrm{ab}$ \\
\hline
\end{tabular}

- Angka-angka yang diikuti oleh huruf yang sama pada kolom yang sama untuk masing-masing tanaman tidak berbeda nyata pada taraf $5 \%$ menurut DNM RT

pada pertanaman dengan guludan memotong lereng $\left(\mathrm{P}_{4}\right.$ dan $\left.\mathrm{P}_{5}\right)$ dibandingkan dengan perlakuan penanaman pada guludan searah lereng $\left(\mathrm{P}_{0}\right)$ (Tabel 3). Hal ini disebabkan rendahnya jumlah erosi pada perlakuan yang mempunyai guludan memotong lereng tersebut (Tabel 1). Dengan kata lain teknik konservasi tanah yang dapat menekan jumlah erosi sekaligus akan menurunkan jumlah bahan organik dan unsur hara yang hilang terbawa erosi, karena kehilangan unsur hara berhubungan lagsung dengan jumlah erosi dan merupakan fungsi dari konsentrasi C-organik dan unsur hara tersebut di dalam sedimen (Sinukaban 2007, Arsyad 2009).

Jumlah C-organik terbawa erosi lebih besar dibandingkan dengan jumlah $\mathrm{N}, \mathrm{P}$ dan
K (Tabel 3, Gambar 1). Hal ini menunjukkan bahwa kehilangan bahan organik akibat erosi merupakan masalah yang lebih serius yakni mempercepat kerusakan tanah. Dalam hal ini penurunan kesuburan tanah berhubungan erat dengan penurunan bahan organik tanah yang berkorelasi dengan kerusakan struktur tanah, meningkatnya kepadatan, menurunnya infiltrasi dan status hara tanah. Oleh karena itu konservasi tanah sekaligus konservasi bahan organik tanah merupakan suatu keharusan pada setiap usaha pertanian, sehingga level bahan organik di dalam tanah merupakan salah satu indikator keberlanjutan sumberdaya lahan (Khisa 2002, Wolf \& Snyder 2003). 

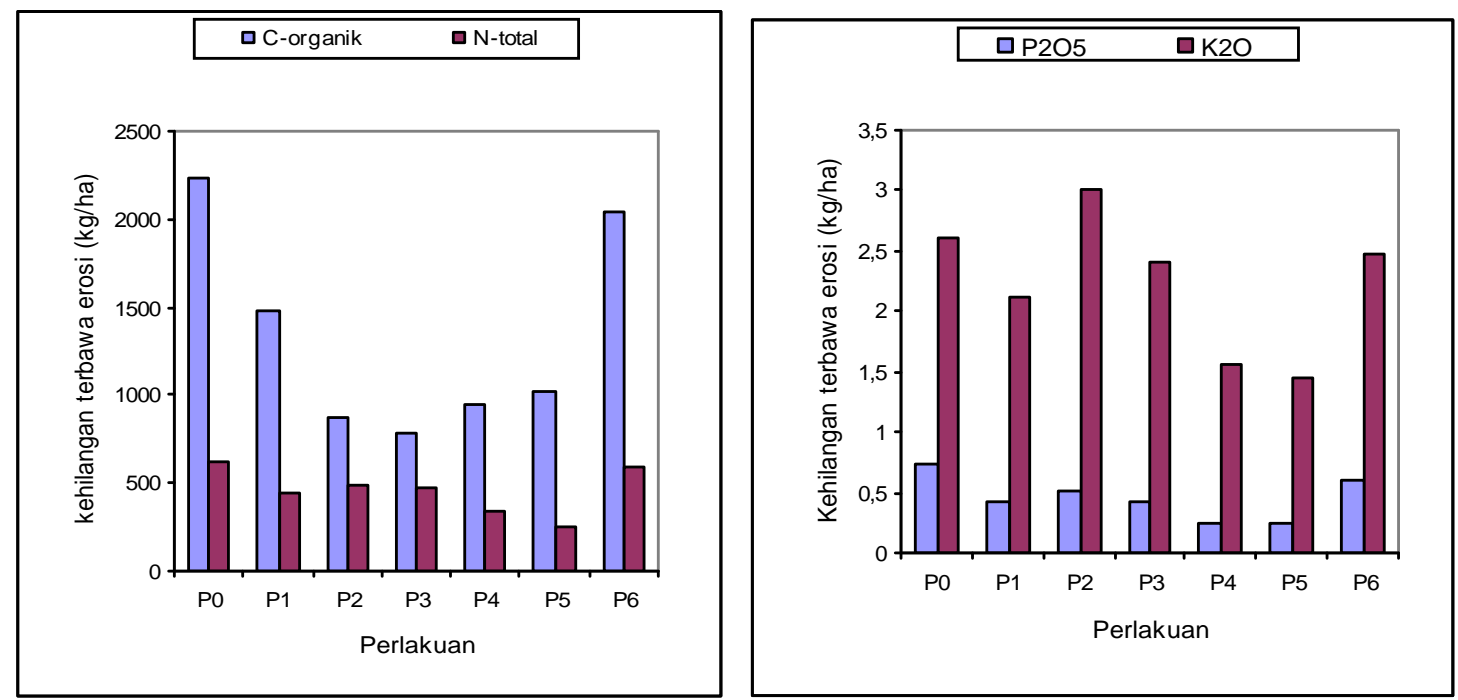

Gambar 1 Pengaruh sistem guludan tanaman kentang terhadap kehilangan C-organik dan $\mathrm{N}$-total (a) serta P2O5 dan K2O (b) terbawa erosi pada Andisol Desa Kebun Baru di hulu DAS Merao, Kecamatan Kayu Aro, Kabupaten Kerinci, Jambi

Jumlah $\mathrm{N}$ yang terbawa erosi jauh lebih besar dibandingkan dengan jumlah $\mathrm{P}$ dan $\mathrm{K}$ (Tabel 3). Hal ini disebabkan oleh $\mathrm{N}$ di dalam tanah merupakan unsur hara yang berasal dari bahan organik tanah dan peningkatan jumlah $\mathrm{N}$ di dalam tanah karena peningkatan kandungan bahan organik tanah dan karena adanya pemberian pupuk $\mathrm{N}$ seperti Urea dan ZA serta melalui air hujan. Namun bahan organik merupakan sumber $\mathrm{N}$ yang utama di dalam tanah (selain unsur hara lainnya seperti $\mathrm{P}$ dan $\mathrm{S}$ ) dengan perbandingan $\mathrm{C}: \mathrm{N}: \mathrm{P}: \mathrm{S}$ adalah $100: 10$ : 1 : 1 (Hardjowigeno 2010). Dengan demikian kehilangan C-organik yang tinggi akibat terbawa erosi diikuti oleh kehilangan $\mathrm{N}$ yang juga cukup besar. Kondisi ini menunjukkan bahwa usahatani kentang sebagai tanaman semusim pada wilayah berlereng akan mempercepat degradasi lahan terutama akibat erosi, penurunan kandungan bahan organik tanah dan kehilangan hara (Stocking 1994). Namun melalui penerapan teknik konservasi tanah yang memadai yang dapat mengendalikan erosi sekaligus juga dapat mengendalikan kehilangan bahan organik dan unsur hara terutama $\mathrm{N}$.

Hasil tanaman dan hubungannya dengan erosi
Hasil kentang dan persentase umbi yang busuk tidak berbeda nyata antar perlakuan (Tabel 4). Namun sebagaimana dijelaskan sebelumnya erosi nyata lebih kecil pada perlakuan dengan guludan memotong lereng $\left(\mathrm{P}_{4}\right)$ atau perlakuan searah lereng dan dipotong dengan guludan memotong lereng pada setiap jarak $4.5 \mathrm{~m}\left(\mathrm{P}_{1}\right.$, $\mathrm{P}_{2}, \mathrm{P}_{3}$ ). Hal ini menunjukkan bahwa arah guludan tidak nyata berpengaruh terhadap faktor-faktor tanah dan lingkungan yang mempengaruhi pertumbuhan dan hasil tanaman, namun mempengaruhi jumlah tanah hilang atau erosi (Gambar 2).

Sebagaimana diketahui bahwa pertumbuhan dan perkembangan kentang sangat dipengaruhi oleh kualitas tanah, terutama drainase dan aerase yang sangat berpengaruh terhadap produksi umbi. Pada tanah berdrainase jelek akan menyebabkan busuknya umbi dan meningkatnya serangan penyakit busuk daun oleh Phytopthora infestans dan penyakit layu oleh Fusarium oxysporum yang berimplikasi pada penurunan produksi umbi (Sunarjono 2008, Duriat et al. 2006). Dalam hal ini tanah pada petak percobaan bertekstur lempung berdebu yang cukup poros (BI rendah, TRP tinggi) (Lampiran 1), sehingga drainase dan aerase tanah cukup baik dan relatif tidak terpengaruh oleh perlakuan arah guludan yang berbeda. Hal ini sekaligus menjawab 
kekhawatiran petani yang beranggapan bahwa penanaman kentang pada guludan memotong lereng akan menurunkan hasil akibat meningkatnya serangan penyakit layu dan busuk umbi dan batang yang dipicu oleh kelembaban yang tinggi di daerah perakaran

Tabel 4. Pengaruh sistem guludan tanaman kentang terhadap hasil kentang pada Andisol Desa Kebun Baru di hulu DAS Merao, Kabupaten Kerinci, Jambi

\begin{tabular}{cccccc}
\hline Perlakuan & Umbi busuk & \multicolumn{3}{c}{ Hasil kentang (ton/ha) ukuran- } & Total \\
\cline { 3 - 5 } & $(\%)$ & $\mathrm{L}(>60 \mathrm{~g})$ & $\mathrm{M}(30-60 \mathrm{~g})$ & $\mathrm{S}(<30 \mathrm{~g})$ & \\
(ton/ha)
\end{tabular}

* Angka-angka pada kolom yang sama tidak berbeda nyata pada taraf $5 \%$ menurut DNMRT

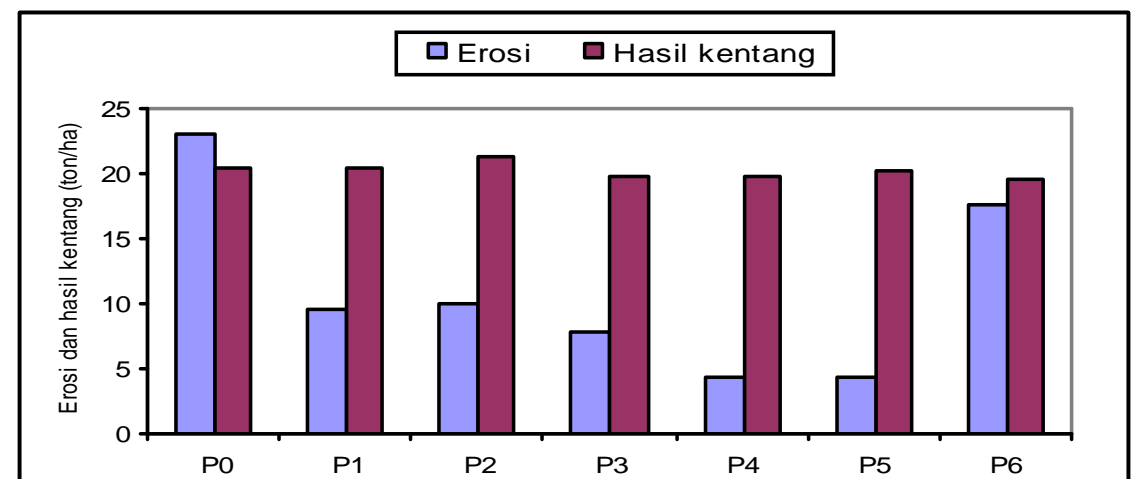

Gambar 2. Pengaruh sistem guludan terhadap erosi dan hasil kentang pada Andisol Desa Kebun Baru di hulu DAS Merao, Kecamatan Kayu Aro, Kabupaten Kerinci, Jambi

\section{KESIMPULAN DAN SARAN}

Hasil penelitian menunjukkan bahwa penanaman kentang pada guludan memotong lereng, atau guludan memotong lereng miring $15^{0}$, atau guludan searah lereng dengan guludan memotong lereng setiap jarak $4.5 \mathrm{~m}$ dapat mengendalikan erosi dan kehilangan hara dan tidak mempengaruhi hasil kentang dibandingkan dengan penanaman pada guludan searah lereng. Penanaman pada guludan searah lereng dengan guludan memotong lereng pada setiap jarak $4.5 \mathrm{~m}$ menekan erosi, kehilangan C-organik dan $\mathrm{N}$ tanah masingmasing 65.89, 65.19 dan 24.55 persen dibandingkan dengan penanaman searah lereng.

\section{DAFTAR PUSTAKA}

Arsyad, S. 2009. Konservasi Tanah dan Air. IPB Press Bogor

[Bappeda] Badan Perencanaan dan Pembangunan Daerah Kabupaten Kerinci. 2004. Penyusunan Master Plan Agribisnis Pariwisata dan Jasa Kabupaten Kerinci. Laporan Rencana. Sungai Penuh: Bappeda Kabupaten Kerinci Bappeda Kabupaten Kerinci 2004).

BP DAS Batanghari. 2003. Rencana Teknik Lapangan Rehabilitasi Lahan dan Konservasi Tanah (RTL-RLKT) DAS Batang Merao. Buku I dan II. Badan Pengelolaan DAS Batanghari. Direktorat Jenderal Rehabilitasi Lahan 
dan Perhutanan Sosial. Departemen Kehutanan.

Duriat, A.S.; O.S. Gunawan dan N. Gunaeni. 2006. Penerapan teknologi PHT pada Tanaman kentang. Monografi No. 28. ISBN : $\quad 979-8304-50-0 . \quad$ Balai Penelitian Tanaman Sayuran. Pusat Penelitian dan Pengembangan Hortikultura. Badan Penelitian dan Pengembangan Pertanian. Departemen Pertanian.

Hardjowigeno, S. 2010. IImu Tanah. Jakarta: Akademika Pressindo.

Haryati, U. dan U. Kurnia. 2000. Pengaruh teknik konservasi terhadap erosi dan hasil kentang (Solanum tuberosum) pada lahan budidaya sayuran di Dataran Tinggi Dieng. Dalam Reorientasi Pendayagunaan Sumberdaya Tanah, Iklim, dan Pupuk. I. Prosiding Seminar Nasional. Pusat penelitian dan Pengembangan tanah dan Agroklimat Bogor. hal 439 - 460

Hidayat, M. dan A. Mulyani. 2002. Lahan Kering untuk Pertanian. Teknologi Pengelolaan Lahan Kering Menuju Pertanian Produktif Ttanah dan Agroklimat Bogor. Hal. 1-34.

Johnson, C.N.; J.V. Mannering and W.C. Moldenhauer. 1979. Influence of surface roughness and clod size and stability on soil and water losses. Soil Sci. Amer. J. 43 : 772-777.

Khisa, K. S. 2002. Farming practices and sustainable development in the Chittagong Hill Tracts. In. N.A. Khan, M. K. Alam and S.K. Khisa (eds). Farming Practices and Sustainable Development in the Chittagong Hill Tracts. CHT Devlopment Board Government of the People's Republic of Bangladesh. p. $49-60$

Kurnia, U.; H. Suganda; D. Erfandi; dan H. Kusnadi. 2004. Teknologi konservasi tanah pada budidaya sayuran dataran tinggi. Dalam Teknologi Konservasi Tanah pada Lahan Kering Berlereng. Pusat Penelitian dan Pengembangan Pertanian. Departemen Pertanian. Hal. : 133-150

Murtilaksono, K. 1998. Constraint affecting the application of soil conservation measures in developing countries. Jurnal Ilmu tanah dan Lingkungan Vol. 1 No.1. Jan. 1998. Hal. 18-25

Sinukaban N. 2007. Membangun Pertanian Menjadi Industri yang Lestari dengan Pertanian Konservasi. Dalam : Konservasi Tanah dan Air. Kunci Pembangunan Berkelanjutan. Ed. Ke1. Dirjen RLPS. Jakarta.

Sinukaban, N.; H. Pawitan; S. Arsyad dan J. Armstrong. 1998. Impact of soil and water conservation practices on stream flows in Citere Catchment,

West Java Indonesia. In. H.P. Blume, H. Eger, E. Fleischhauer, A. Hebel, C. Reij, K. G. Steiner (Eds.) Towards Sustainable Land Use. Vol. II.In. Advances in Geoecology 31, 12751280.

Sitorus, S.R.P. dan W. Tirtohadisurjo. 1979. Penuntun praktikum konservasi tanah. Departemen Ilmu-ilmu Tanah Fakultas Pertanian IPB. Bogor.

Suganda H., Kusnadi H., Kurnia U. 1999. Pengaruh arah barisan tanaman dan bedengan dalam pengendalian erosi pada budidaya sayuran dataran tingi. Tanah dan I klim 17: 55-64

Sunarjono, H. H. 2007. Petunjuk Praktis Budidaya Kentang, PT. AgroMedia Pustaka. Jakarta

Wolf, B. and G.H. Snyder. 2003. Sustainable Soils. The Place of Organic Matter in Sustainability Soils and Their Productivity. Food Product Press. New York. London. 
Lampiran 1. Sifat fisika dan kimia tanah (sebelum perlakuan) Andisol Kebun Baru di hulu DAS Merao, Kecamatan Kayu Aro, kabupaten Kerinci, Jambi

\begin{tabular}{|c|c|c|c|}
\hline \multirow[t]{2}{*}{ Sifat tanah } & \multicolumn{3}{|c|}{ Kelompok } \\
\hline & I & II & III \\
\hline Tekstur & \multicolumn{3}{|c|}{ lempung berdebu } \\
\hline Pasir (\%) & 20.56 & 21.04 & 20.88 \\
\hline Debu $(\%)$ & 73.10 & 70.32 & 74.06 \\
\hline Liat $(\%)$ & 6.34 & 8.64 & 5.06 \\
\hline $\mathrm{pH}$ & 5.20 & 5.00 & 5.20 \\
\hline C-organik (\%) & 12.09 & 11.12 & 13.90 \\
\hline N-total (\%) & 0.36 & 0.29 & 0.46 \\
\hline P-tersedia (ppm) & 21.70 & 12.00 & 21.70 \\
\hline \multicolumn{4}{|l|}{ Basa dapat ditukar } \\
\hline Ca-dd (me/1000g) & 6.14 & 3.02 & 8.24 \\
\hline Mg-dd (me/100g) & 3.26 & 1.24 & 3.40 \\
\hline K-dd (me/100g) & 0.20 & 0.18 & 0.20 \\
\hline Na-dd (me/100g) & 0.20 & 0.18 & 0.20 \\
\hline KTK (me/100g) & 29.34 & 27.98 & 36.88 \\
\hline $\mathrm{KB}(\%)$ & 34.00 & 17.10 & 33.30 \\
\hline Bobot isi $\left(\mathrm{g} / \mathrm{cm}^{3}\right)$ & 0.53 & 0.64 & 0.41 \\
\hline Porositas (\%) & 80.03 & 75.71 & 84.70 \\
\hline Pori drainase sangat cepat (\% vol) & 19.61 & 16.41 & 15.61 \\
\hline Pori drainase cepat (\% vol) & 8.87 & 14.17 & 13.61 \\
\hline Pori drainase lambat (\% vol) & 9.46 & 8.60 & 10.71 \\
\hline Pori air tersedia (\% vol) & 16.88 & 13.23 & 18.33 \\
\hline Permeabilitas $(\mathrm{cm} / \mathrm{jam})$ & 21.36 & 17.26 & 21.47 \\
\hline
\end{tabular}

